International Research Journal of Engineering, IT \& Scientific Research
Available online at https://sloap.org/journals/index.php/irjeis/
Vol. 7 No. 1 January 2021, pages: 1-9
ISSN: 2454-2261
https://doi.org/10.21744/irjeis.v7n1.1176

\title{
Blended Learning is an Educational Innovation and Solution During the COVID-19 Pandemic
}

\author{
I Gede Made Karma a \\ I Ketut Darma ${ }^{\text {b }}$ \\ I Made Anom Santiana ${ }^{c}$
}

Article history:

Submitted: 27 November 2020

Revised: 09 December 2020

Accepted: 18 January 2021

\section{Keywords:}

blended learning;

interactive communication;

pandemic;

problem-based;

smartphone;

\begin{abstract}
The COVID-19 pandemic has indeed forced people to do more activities from home, including the learning process. The learning from home policy is not accompanied by rules and regulations such as what this learning process should be carried out. As a result, various learning processes emerged, from what they are to complex things. This study aims to find innovations and learning solutions during a pandemic, to support learning from home. Online learning is the only option. It's just that, based on the problems and constraints revealed, this online learning must be packaged like traditional face-to-face learning. The choice then turned to blended learning, with various adjustments. Face-to-face learning is carried out via video conference if needed only. The shortcomings are then overcome by compiling learning materials in the form of problem-based, text-based, video, or multimedia practical guides. The learning process is complemented by the opening of active interactive communication channels. Learning evaluation is carried out not only on results but also considering the process and self-evaluation. All of this learning process should be as optimal as possible using a mobile device or smartphone.
\end{abstract}

International research journal of engineering, IT \& scientific research (C) 2021. This is an open access article under the CC BY-NC-ND license (https://creativecommons.org/licenses/by-nc-nd/4.0/).

\section{Corresponding author:}

I Gede Made Karma,

Politeknik Negeri Bali, Indonesia, Bukit Jimbaran, 80364 Kuta Selatan, Tuban Badung Bali, Indonesia.

Email address: igmkarma@pnb.ac.id

\footnotetext{
a Politeknik Negeri Bali, Indonesia, Bukit Jimbaran, 80364 Kuta Selatan, Tuban Badung Bali, Indonesia

b Politeknik Negeri Bali, Indonesia, Bukit Jimbaran, 80364 Kuta Selatan, Tuban Badung Bali, Indonesia

${ }^{\mathrm{c}}$ Politeknik Negeri Bali, Indonesia, Bukit Jimbaran, 80364 Kuta Selatan, Tuban Badung Bali, Indonesia
} 


\section{Introduction}

The outbreak of the COVID-19 pandemic has disrupted human activities around the world. To prevent people from contracting this deadly virus, various policies have been issued by the government. The essence of these policies is to restrict the activities of residents outside the home. If not forced, residents are advised not to leave the house. Wherever possible, do activities from home. Many industrial areas, offices, shopping, tourist attractions have been closed. Even if it is opened, it is monitored with strict health protocols. This government policy has been followed up by various groups by implementing a work from home policy.

This government policy does not only apply to businesses, industries, and offices. This policy applies to all activities of the population, including educational activities. The learning process is no longer allowed at school or campus. Learning must be done from home. Although the learning from home was not explained as to what it was, what was clear was then translated as online learning, with various stories that accompany it. The implementation of the learning from home policy, which was later translated as online learning, was not followed by the issuance of rules/standards for implementing online learning. The process and method of implementation are more left up to the teacher/lecturer. The emphasis is on students to keep studying, not wandering out of the house. As a result, various online learning processes have emerged. Some are very simple by only using the application to send messages via cellphone, to the online learning process using a learning management system, complete with video meetings. One of the contributing factors is the lack of understanding and experience of teachers/lecturers in online learning. Some are used to it, but it must be admitted that the majority do not understand and have experience.

Talking about learning at home in the sense that learning is done alone outside the classroom has long been known in the world of education. In the distance education system, students only occasionally come to class, the rest they study at home with modules. Unfortunately, this process is only popular among distance education implementers. For others, they are accustomed to and focused on traditional learning, face-to-face in class. With current technological developments, followed by the faster and wider reach of the Internet, online learning is not an impossible thing to do. Various methods and models of online learning are known, from simple to complex ones. Some are free, some are paid. With the improvement of people's computer and Internet literacy, it is certainly not an obstacle in the implementation of this online learning.

The integration of web-based education and learning through a learning management system (LMS) has enabled educational institutions to carry out the learning process off-campus (Samarawickrema \& Stacey, 2007). The application of this LMS is directed at supporting the increase in the level of satisfaction of students, related to the learning process that is followed (Ozkan \& Koseler, 2009). Various parties have acknowledged that an integrated learning model that utilizes e-learning can have a positive impact on students if it is linked to learning motivation and learning outcomes they achieve (Alkhalaf et al., 2012; Tambunan et al., 2018). Various approaches to learning models, including planning, development, process, and evaluation, can be applied. What deserves attention is how to increase student participation and motivation, which in turn is expected to increase student success (Czerkawski \& Lyman, 2016). One way that many have taken is by utilizing technology. In addition to being able to increase participation, the use of technology allows students to learn flexibly, not limited by place and time. The integration of this technology is believed to be able to increase student activity and learning achievement (Bower et al., 2015).

The rapid development of information technology and multimedia, with the various conveniences that accompany it, has been able to change the lifestyle of some people, especially teenagers. The ease of obtaining various content, including interactive learning materials in the form of multimedia files from the Internet, has given them a different impression and experience (Evans, 2008). Regarding the learning process, some of them don't really like conventional learning anymore. They are more interested in learning processes that are relevant, interesting, and challenging (Garrison \& Vaughan, 2008). The choice of online learning during this pandemic was indeed felt right. Several advantages can be found with the application of online learning, such as the flexibility of time and place to learn and the ease of accessing information (Pande et al., 2016). However, behind these various advantages, the problem of learning quality should receive special attention. Learning materials must be well prepared, by taking advantage of the convenience of technology so that it has an impact on increasing student satisfaction (Sun et al., 2008). 


\section{Materials and Methods}

\section{The development of online learning}

The development of computer and internet technology has greatly influenced the way of life of humans. Various kinds of facilities have been offered by taking advantage of this technology. The presence of information technology (IT) has made it possible to store, select and disseminate a variety of information, including knowledge, broadly and efficiently (Altbach \& Knight, 2007). As a result, various kinds of facilities have been offered by taking advantage of this technology. By utilizing computer devices and other electronic devices, such as smartphones, online learning has made it possible and widely applied, which is known as e-learning (Ellis \& Goodyear, 2013). E-learning is mostly implemented by exploiting various applications and technological features that already exist and are common in this society (Alonso et al., 2005b).

The popularity of various social software, especially for young people, has led many educators to think that this practice and enthusiasm can be transferred to educational uses. The presence of television media and videoconferencing devices, computer-based training, and artificial intelligence technology, as well as the availability of various kinds of assistive devices, further encourage their use in education (Rennie \& Morrison, 2013). Various media and technologies are used to support learning models which are categorized as e-learning (Sife et al., 2007), with their respective goals and advantages, as presented in Table 1.

Table 1

Instructional media, uses, and disadvantages

\begin{tabular}{lll}
\hline Media Type & Uses & Disadvantages \\
\hline TV/Radio & $\begin{array}{l}\text { The dissemination of audiovisual } \\
\text { teaching materials guided by the } \\
\text { presenter takes place interactively / not. }\end{array}$ & $\begin{array}{l}\text { Success is determined by the packaging } \\
\text { of the event, including giving } \\
\text { instructions, explanations, questions, and } \\
\text { evaluations at each event. }\end{array}$ \\
Video & $\begin{array}{l}\text { In the form of recorded material that } \\
\text { emphasizes practical demo or audiovisual } \\
\text { stimulation. }\end{array}$ & $\begin{array}{l}\text { Highly dependent on the packaging, } \\
\text { repeatable. There is practically no } \\
\text { interaction, and independence is needed. }\end{array}$ \\
Anternet & $\begin{array}{l}\text { Access to content freely and almost } \\
\text { unlimitedly, which can be selected } \\
\text { according to interests. }\end{array}$ & $\begin{array}{l}\text { The updating of the material depends on } \\
\text { the manager, and there may be public and } \\
\text { open interactions. }\end{array}$ \\
Messaging & $\begin{array}{l}\text { Interactive distribution of content related } \\
\text { to certain studies, in a limited } \\
\text { application }\end{array}$ & $\begin{array}{l}\text { Activities and discussions are very much } \\
\text { determined by the existing personnel. }\end{array}$ \\
Video conference & $\begin{array}{l}\text { Two-way audiovisual interaction } \\
\text { Are dynamic and can integrate various } \\
\text { E-learning platform }\end{array}$ & $\begin{array}{l}\text { Constrained quota and internet signal } \\
\text { It takes good management and } \\
\text { infrastructure. }\end{array}$ \\
\hline
\end{tabular}

The variety of learning media that can be used and categorized as e-learning has encouraged related parties to choose and apply it in their way. Generally, the teachers as initiators, take advantage of this e-learning media as a medium for sharing, repeating, and completing learning content that is carried out in class (Singh, 2003). The existence of elearning is effectively utilized in the learning process at universities and is felt to be very helpful for students in the learning process (Laurillard, 2006).

\section{Blended learning}

Sometimes, the use of e-learning is still not effective. In addition to the limitations that each existing learning model has, many are still very dependent on face-to-face learning. Then comes an effort to combine and collaborate both on a new methodology called blended learning, and it has become a learning model that is felt to be the most effective (Azizan, 2010). The presence of teachers and students physically, like classical learning, is possible in blended learning. This is done by combining internet technology and other digital media into classrooms (Friesen, 2012).

Karma, I. G. M., Darma, I. K., \& Santiana, I. M. A. (2021). Blended Learning is an Educational Innovation and Solution During the COVID-19 Pandemic. International Research Journal of Engineering, IT \& Scientific Research, 7(1), 1-9. https://doi.org/10.21744/irjeis.v7n1.1176 
Even though in its application the term "mixed learning" does not match the meaning it has (Pina, 2004). What is clear is that in blended learning there is an effort to balance online access between knowledge and human interaction, such as in classroom learning (Graham \& Dziuban, 2008). This has aroused the interest of many people to know, understand and try to apply it (Graham, 2011). Blended learning, as the name implies, is a learning process that combines face-to-face learning in class, with online learning through Internet media, and other technologies. The application of this learning process is to make the achievement of the learning process more effective (Hoic-Bozic et al., 2009). In its application, blended learning emphasizes the use of technology to support and improve the learning process itself (Tyley, 2012), as well as increasing student motivation so that it is successful in achieving learning goals well (Johnson \& Aragon, 2003).

In its implementation, blended learning "mixes" various components of traditional and online learning. By utilizing existing technology and media, blended learning organizes the learning process, delivery of learning materials, and other learning activities, with different methods, namely combining traditional and online methods. Interaction during the learning process, both individually and in groups, is carried out synchronously and asynchronously (Alonso et al., 2005a; Thorne, 2003). In line with the current development and situation, the use of blended learning by academics has become a good and encouraging trend (Cohen, 1998). Some groups considered that there was a significant increase in student achievement after the implementation of the learning process using the blended learning model (Kiviniemi, 2014). This of course indicates that the blended learning model is very appropriate to be applied (Stockwell et al., 2015).

\section{Results and Discussions}

\section{Online learning survey results}

The implementation of the work from home policy also has an impact on the learning process which must also be done online. This raises the desire to know what the behavior or habits of the Bali State Polytechnic lecturers and students are. Finally, an online survey was distributed especially in the campus environment, and it was responded to by 588 lecturers ( 26 people) and students (562 people). The survey results showed that only $46.8 \%$ of respondents stated that they were familiar with online learning, as many as $48 \%$ of respondents only used it occasionally and the rest, around $5.2 \%$ of respondents said they had never done it at all. This shows that the majority of them are familiar with online learning.

Then, what do they do with this online learning? As many as $57.5 \%$ stated that they were related to assigning and collecting assignments, $20.5 \%$ conducted a discussion of subject matter, $15.4 \%$ distributed learning materials, while the rest carried out evaluations in the form of tests (3.4\%) and explanations of subject matter (2.4\%). Even though it is dominated by matters relating to assignments, practically all matters related to the learning process can / have / can be done online. What is interesting, in terms of the media used, it turns out that very many (35.5\%) rely on learning to use chat media, such as the WA, Line, and Telegram applications. As many as $25.3 \%$ used an online Learning Management System, and $38.1 \%$ used a combination of existing media. Interestingly, only $0.7 \%$ carry out online learning that uses video meeting media specifically. The dominant devices they use to access learning media are smartphones $(67.7 \%)$ and computers/laptops $(32.3 \%)$.

From their experience following online learning, they experienced various obstacles/difficulties. Quite some people complained about the problem of limited internet connection (49.7\%), which is related to poor signals and the high internet quota they have to pay. The majority of them (57.4\%) find it difficult to understand online learning. Quite a few $(22.1 \%)$ are concerned about the lack of interaction between students and lecturers in online learning. The problem of displaying/presenting learning material that is less attractive and boring is also a problem for them $(9.9 \%)$. This is certainly something that should be considered in the application of online learning.

Regarding online learning, there are around $8.4 \%$ of respondents think that learning is not suitable for the application. Implicitly it can be said that they do not agree with the application of online learning. As many as 39.9\% of respondents thought that online learning was suitable to be used as a complement to traditional face-to-face learning. This means that they still think face-to-face learning is the most important. Interestingly, there are $14 \%$ of respondents stated that online learning is suitable to be applied as an alternative to traditional face-to-face learning. However, the majority $(85.4 \%)$ of respondents wanted online learning not to exceed $50 \%$ of the general lecture implementation portion. If explored further regarding the implementation of lectures, as many as $26.7 \%$ of respondents stated that lectures must be carried out in full face-to-face, $35 \%$ stated that it could be done together with 
online learning, $33.8 \%$ could be interspersed with online learning and only $4.4 \%$ who said it could be done in full online. From the results of this survey, it can be seen that students are still very dependent on traditional lectures, face to face in class. This also implies that the independence of students in learning is still quite low, and direct guidance from lecturers is important.

\section{Problems and solutions}

As previously explained, the COVID-19 epidemic has resulted in the enactment of an online learning policy. To prevent the spread of this virus from becoming more widespread, the implementation of face-to-face lectures is not enforced until an unclear time limit. Like it or not, online learning is a must. Departing from the survey results and to maintain the quality of learning, this online learning needs to be planned and prepared as well as possible. Based on the survey results, several things must get the attention of the implementers of this online learning, as presented in Table 2.

Table 2

The fact or problems and solutions from online learning

\begin{tabular}{|c|c|}
\hline Fact or problems & Solutions \\
\hline $\begin{array}{l}\text { Face-to-face learning is } \\
\text { mandatory }\end{array}$ & $\begin{array}{l}\text { Face-to-face learning can still be done online using video meeting } \\
\text { applications. }\end{array}$ \\
\hline $\begin{array}{l}\text { Guidance from lecturers is } \\
\text { important }\end{array}$ & $\begin{array}{l}\text { In addition to utilizing communication media in online learning } \\
\text { applications, guidance can also be carried out in class communication } \\
\text { groups consisting of lecturers and students. }\end{array}$ \\
\hline $\begin{array}{l}\text { Teaching materials that are } \\
\text { difficult to understand }\end{array}$ & $\begin{array}{l}\text { Lecture material is not only limited to material from lecturers but can } \\
\text { be combined with additional material from various sources on the } \\
\text { Internet. Material is not only in the form of text but can be } \\
\text { complemented by material in the form of audio-visual or multimedia. }\end{array}$ \\
\hline $\begin{array}{l}\text { Interaction between students } \\
\text { and lecturers is limited. }\end{array}$ & $\begin{array}{l}\text { Online learning provides wider interaction opportunities for students } \\
\text { and lecturers to interact, for example by setting up discussion forums } \\
\text { or questions and answers. Interaction can also be done by utilizing } \\
\text { class communication groups. }\end{array}$ \\
\hline Utilization of mobile devices. & $\begin{array}{l}\text { There are more and fewer uses of this mobile device. Communication } \\
\text { and interaction is certainly not an obstacle. However, for the } \\
\text { presentation of learning content, it is necessary to pay attention to the } \\
\text { "limitations" of mobile devices. }\end{array}$ \\
\hline $\begin{array}{l}\text { Limited and difficult internet } \\
\text { access. }\end{array}$ & $\begin{array}{l}\text { Even though this is a classic problem, it is real. Online learning must } \\
\text { be designed in such a way that it does not always depend on the } \\
\text { internet. Learning materials must be accessible with the smallest } \\
\text { internet needs so that they are not burdensome. }\end{array}$ \\
\hline
\end{tabular}

With the ability to integrate traditional face-to-face learning with multimedia-based and online learning, the blended learning model can be considered the most appropriate solution to overcome these various obstacles. It takes careful planning and consideration before implementing this blended learning. 3 important things deserve attention, namely the curriculum, learning strategies, and technology choices that might be applied (Garrison \& Vaughan, 2008; Lim et al., 2007). In preparing the learning design, these three components must be considered. Discussion of the curriculum will guide what topics/materials should be taught to students. Concerning the teaching goals/objectives, appropriate learning strategies for each topic are determined. In choosing this strategy, the factor of the availability of learning technology should be considered. The ability to integrate these three things will determine our success in implementing blended learning (Karma et al., 2019). Situation factors and conditions related to the learning environment will also influence our learning design. In planning and implementing blended learning, various considerations must be considered. In addition to classical problems such as materials, learning processes, and outcomes, learning climate factors, interaction, and mastery of technology also deserve attention (Wu et al., 2010). Furthermore, the blended learning adoption process must be carried out institutionally. Through the stages of

Karma, I. G. M., Darma, I. K., \& Santiana, I. M. A. (2021). Blended Learning is an Educational Innovation and Solution During the COVID-19 Pandemic. International Research Journal of Engineering, IT \& Scientific Research, 7(1), 1-9. https://doi.org/10.21744/irjeis.v7n1.1176 
exploration, adoption and implementation, strategies, structures and problems that must be solved at each stage can be identified (Porter et al., 2014).

\section{Blended Learning Design}

Of the six main problems faced related to the learning process, the 2 most important things deserve attention, namely compulsory face-to-face learning and limited internet services. Face-to-face learning in the blended learning model can indeed be implemented with video meeting applications such as Zoom, Google Meet, Webex, or other video conference applications. Even though in a certain period the use of this application is free, but from the quota usage system, parents feel quite burdensome for the students. So it needs consideration, if it's not needed, face-to-face online learning doesn't need to be done. It is enough to do it once in a while if it feels really necessary.

The loss or reduction in face-to-face meetings will certainly have an impact on the disappearance of things that occur during face-to-face meetings. The most important thing missing is direct interaction and practical guidance regarding the material being taught. Direct interaction can be overcome by opening channels for various communication media, either through comment channels on the online learning platform used, or by using other communication media such as Line, WA, Telegram, or other applications that are popular among smartphone users. Meanwhile, practical guides can be replaced with written guides that are distributed to students. Just keep in mind, for some people, reading is something that is not interesting or liked. The alternative that is done later is to make practical learning videos. This is certainly not an easy thing, but it is worth considering.

Practical guidance materials for certain materials, either in writing or instructional videos, will certainly be of great help to students who experience problems due to lack of guidance from lecturers, or difficulty understanding teaching materials. In terms of internet quota usage, the distribution of a web-based online written guide or a softcopy of the file being shared, of course, requires a smaller quota compared to the video. For those who are lazy to read, especially if a video can be played repeatedly, video is an option. Another thing that deserves attention is the dominant use of mobile devices, compared to computer devices. Because the online learning process is anytime and anywhere, the use of mobile devices is appropriate. However, mobile devices have some limitations, which can be distracting and difficult in this online learning process. This limitation is related to the limited memory and screen capacity. The most annoying thing is the small screen of the device, so it needs a good web-based online learning display setting that is easy to control.

The lack of or limited interaction can be partially overcome by opening up possible communication channels. The key lies in the activities and initiatives of all parties, especially students. To be more focused and focused, communication can be arranged on a scheduled basis with certain topics/problems. For passive participants, the lecturer can take the initiative by greeting or asking light questions to open the interaction. The blended learning model that is planned must refer to a constructive learning process based on problem-solving by implementing a Learning Management System supported by multimedia (Darma et al., 2020). Online learning requires independence, motivation, and a high interest in learning. On the other hand, one of the obstacles faced is the difficulty of understanding the teaching material provided. Therefore, it is very natural that alternative teaching materials are needed (Darma et al., 2020). In the preparation of teaching materials, the description of the material should use a problem-solving approach, which is equipped with student activity sheets. A systematic explanation that is equipped with examples of cases and their solutions, of course, helps accelerate students' understanding of the material being taught (Darma et al., 2020). Evaluations related to the assessment of learning outcomes are not only emphasized on results but also related to the process that students go through. Evaluation is carried out using a performance-based approach that refers to portfolios and self-evaluation (Darma et al., 2019).

\section{Conclusion}

Blended learning is the right choice and solution in the current COVID-19 pandemic. The approach taken is to combine traditional learning patterns with online multimedia-based information technology. Constraints and obstacles that exist in the learning environment deserve attention. In addition to technical factors related to technological mastery and access constraints, the preparation of problem-based materials equipped with cases and problem-solving guides, coupled with active interactive communication media channels, is believed to be able to improve student learning activities. In the end, the effectiveness of the learning process using the blended learning model will be achieved properly. 
Conflict of interest statement

The authors declared that they have no competing interests.

Statement of authorship

The authors have a responsibility for the conception and design of the study. The authors have approved the final article.

\section{Acknowledgments}

The author would like to thank the Directorate of Research and Community Service, Deputy for Strengthening Research and Development, Ministry of Research and Technology / National Research and Innovation Agency for funding the implementation of this research. Thanks and appreciation to the team of the Research and Community Service Center of Politeknik Negeri Bali for their direction and guidance.

Karma, I. G. M., Darma, I. K., \& Santiana, I. M. A. (2021). Blended Learning is an Educational Innovation and Solution During the COVID-19 Pandemic. International Research Journal of Engineering, IT \& Scientific Research, 7(1), 1-9. https://doi.org/10.21744/irjeis.v7n1.1176 


\section{References}

Alkhalaf, S., Drew, S., Alghamdi, R., \& Alfarraj, O. (2012). E-learning system on higher education institutions in KSA: Attitudes and perceptions of faculty members. Procedia-Social and Behavioral Sciences, 47, 1199-1205. https://doi.org/10.1016/j.sbspro.2012.06.800

Alonso, F., López, G., Manrique, D., \& Viñes, J. M. (2005). Un modelo de aprendizaje basado en la web de elearning educación con un enfoque de aprendizaje combinado. British Journal of Educational Technology.

Alonso, F., López, G., Manrique, D., \& Viñes, J. M. (2005). Un modelo de aprendizaje basado en la web de elearning educación con un enfoque de aprendizaje combinado. British Journal of Educational Technology.

Altbach, P. G., \& Knight, J. (2007). The internationalization of higher education: Motivations and realities. Journal of studies in international education, 11(3-4), 290-305.

Azizan, F. Z. (2010). Blended learning in higher education institution in Malaysia. In Proceedings of regional conference on knowledge integration in ICT (Vol. 10, pp. 454-466).

Pina, AB (2004). Blended learning. Basic concepts. Pixel-Bit. Journal of media and education , (23), 7-20.

Bower, M., Dalgarno, B., Kennedy, G. E., Lee, M. J., \& Kenney, J. (2015). Design and implementation factors in blended synchronous learning environments: Outcomes from a cross-case analysis. Computers \& Education, 86, 1-17. https://doi.org/10.1016/j.compedu.2015.03.006

Cohen, D. (1998). Chronicle of Higher Education. The Women's Review of Books, 15(5), 27-27.

Czerkawski, B. C., \& Lyman, E. W. (2016). An instructional design framework for fostering student engagement in online learning environments. TechTrends, 60(6), 532-539.

Darma, I. K., Karma, I. G. M., \& Santiana, I. M. A. (2020). Needs Analysis Development of Applied Mathematical Blended Learning Models Using Schoology LMS. In Journal of Physics: Conference Series (Vol. 1569, No. 4, p. 042060). IOP Publishing.

Darma, I. K., Karma, I. G. M., \& Santiana, I. M. A. (2019). The Development of Blended Learning Model in Applied Mathematics by Using LMS Schoology: Requirement Analysis Stage. International Research Journal of Engineering, IT and Scientific Research, 5(6), 33-45.

Darma, I. K., Karma, I. G. M., \& Santiana, I. M. A. (2020, September). Need analysis for developing applied mathematics textbooks based on blended learning to improve problem solving abilities at the students of polytechnic state of Bali. In AIP Conference Proceedings (Vol. 2268, No. 1, p. 030004). AIP Publishing LLC.

Darma, I. K., Karma, I. G. M., Santiana, I. M. A., \& Irene, E. (2020). Need Analysis for Developing Applied Mathematics Teaching Materials Based on Blended Learning to Improve Communication and Problem Solving Abilities by the Students of State Polytechnic of Bali. Soshum: Jurnal Sosial dan Humaniora, 10(2), $183-196$.

Ellis, R., \& Goodyear, P. (2013). Students' experiences of e-learning in higher education: the ecology of sustainable innovation. Routledge.

Evans, C. (2008). The effectiveness of m-learning in the form of podcast revision lectures in higher education. Computers \& education, 50(2), 491-498. https://doi.org/10.1016/j.compedu.2007.09.016

Friesen, N. (2012). Report: Defining blended learning.

Garrison, D. R., \& Vaughan, N. D. (2008). Blended learning in higher education: Framework, principles, and guidelines. John Wiley \& Sons.

Graham, C. R. (2011). Blended Learning Models. In Encyclopedia of Information Science and Technology, Second Edition. https://doi.org/10.4018/978-1-60566-026-4.ch063

Graham, C. R., \& Dziuban, C. D. (2008). Blended Le arning Environments. Handbook of Research on Educational Communications and Technology. https://doi.org/10.1080/02652030701883203

Hoic-Bozic, N., Mornar, V., \& Boticki, I. (2008). A blended learning approach to course design and implementation. IEEE transactions on education, 52(1), 19-30.

Johnson, S. D., \& Aragon, S. R. (2003). An instructional strategy framework for online learning environments. New directions for adult and continuing education, 2003(100), 31-43.

Karma, I. G. M., Darma, I. K., \& Santiana, I. M. A. (2019). Teaching strategies and technology integration in developing blended learning of applied mathematics subject. International Research Journal of Engineering, IT and Scientific Research, 5(5), 16-25.

Kiviniemi, M. T. (2014). Effects of a blended learning approach on student outcomes in a graduate-level public health course. BMC medical education, 14(1), 1-7.

Laurillard, D. (2006). E-learning in higher education. Changing higher education: The development of learning and teaching, 3, 71-84.

Lim, D. H., Morris, M. L., \& Kupritz, V. W. (2007). Online vs. blended learning: Differences in instructional 
outcomes and learner satisfaction. Journal of Asynchronous Learning Networks, 11(2), 27-42.

Ozkan, S., \& Koseler, R. (2009). Multi-dimensional students' evaluation of e-learning systems in the higher education context: An empirical investigation. Computers \& Education, 53(4), 1285-1296. https://doi.org/10.1016/j.compedu.2009.06.011

Pande, D., Wadhai, V. M., \& Thakare, V. M. (2016). E-learning system and higher education. International Journal of Computer Science and Mobile Computing, 5(2), 274-280.

Porter, W. W., Graham, C. R., Spring, K. A., \& Welch, K. R. (2014). Blended learning in higher education: Institutional adoption and implementation. Computers \& Education, 75, 185-195. https://doi.org/10.1016/j.compedu.2014.02.011

Rennie, F., \& Morrison, T. (2013). E-learning and social networking handbook: Resources for higher education. Routledge.

Samarawickrema, G., \& Stacey, E. (2007). Adopting Web-Based Learning and Teaching: A case study in higher education. Distance education, 28(3), 313-333.

Sife, A., Lwoga, E., \& Sanga, C. (2007). New technologies for teaching and learning: Challenges for higher learning institutions in developing countries. International journal of education and development using ICT, 3(2), 57-67.

Harvey, S. (2003). Building effective blended learning programs. Educational Technology, 43(6), 51-54.

Stockwell, B. R., Stockwell, M. S., Cennamo, M., \& Jiang, E. (2015). (2015) Blended Learning Improves Science Education. Cell, 162 (5), 933-936. Available online from doi. org.

Sun, P. C., Tsai, R. J., Finger, G., Chen, Y. Y., \& Yeh, D. (2008). What drives a successful e-Learning? An empirical investigation of the critical factors influencing learner satisfaction. Computers \& education, 50(4), 1183-1202. https://doi.org/10.1016/j.compedu.2006.11.007

Tambunan, L., Rusdi, R., \& Miarsyah, M. (2018). Efectiveness of Problem Based Learning Models by Using ELearning and Learning Motivation Toward Students Learning Outcomes on Subject Circullation Systems. Indonesian Journal of Science and Education, 2(1), 35-43.

Thorne, K. (2003). Blended learning: how to integrate online \& traditional learning. Kogan Page Publishers.

Tyley, S. (2012). Blended learning. Fire Risk Management.

Wu, J. H., Tennyson, R. D., \& Hsia, T. L. (2010). A study of student satisfaction in a blended e-learning system environment. Computers \& Education, 55(1), 155-164. https://doi.org/10.1016/j.compedu.2009.12.012

Karma, I. G. M., Darma, I. K., \& Santiana, I. M. A. (2021). Blended Learning is an Educational Innovation and Solution During the COVID-19 Pandemic. International Research Journal of Engineering, IT \& Scientific Research, 7(1), 1-9. https://doi.org/10.21744/irjeis.v7n1.1176 